\title{
PENGARUH EFIKASI DIRI DAN PENGETAHUAN KEWIRAUSAHAAN TERHADAP MINAT BERWIRAUSAHA MELALUI MOTIVASI
}

\author{
Flora Puspitaningsih, \\ florapuspita70@gmail.com
}

\begin{abstract}
ABSTRAK
Penelitian ini bertujuan untuk menganalisis pengaruh efikasi diri dan pengetahuan kewirausahaan terhadap minat berwirausaha melalui motivasi. Populasi dalam penelitian ini adalah mahasiswa STKIP PGRI Tulungagung Prodi PKn, Prodi Matematika dan Prodi Ekonomi sebanyak 619 orang dengan jumlah sampel sebanyak 243 orang. Adapun teknik pengumpulan data yang digunakan yaitu dengan angket terbuka dan tertutup. Metode analisis menggunakan Structural Equation Modeling (SEM). Dengan menggunakan teknik probabilily sampling. Hasil penelitian menunjukan bahwa : (1) Efikasi diri berpengaruh tidak terhadap motivasi ; (2) efikasi diri berpengaruh terhadap minat; (3) pengetahuan kewirausahaan berpengaruh terhadap motivasi; (4) pengetahuan kewirausahaan tidak berpengaruh terhadap minat ; (5) Motivasi berpengaruh terhadap minat; (6) Motivasi tidak berfungsi sebagai variabel mediasi pada pengaruh efikasi dan (7) Motivasi berfungsi sebagai variabel mediasi pada pengetahuan kewirausahaan terhadap minat wirausaha.
\end{abstract}

Kata Kunci : efikasi diri, pengetahuan kewirausahaa, motivasi, minat berwirausaha

\begin{abstract}
The objective of this study is to analyze the effect of self efficacyand entreprenuership knowledge on entreprenuer willing throught motivation. The population of this study are student of STKIP PGRI Tulungagung in Civies Education Program, Mathematic department and economic department taht consist of 619 student. Then the sample taken are 243 student. Open and closed question are used as collecting data technique Structural Equation Modelling (SEM) is used as a method of data analysis. And use problabing sample method. The finding shows that: 1) self efficacy is not significantly effect on student motivation, 2) self efficacy effect significantly on student willing, 3) entreprenuership knowledge effect significantly on student motivation, 4) entreprenuership knowledge is not significantly effect on student entreprenuer willing, 5) motivation effect on student entreprenuer willing, 6) motivation do not fuction as mediation variable on the effect of self efficacy and entreprenuership knowledge on student willing of entreprenuer.
\end{abstract}

Keywords: Self Efficacy, Entreprenuership Knowledge, Motivation and Enterprenuer Willing. 


\section{PENDAHULUAN}

Dalam suatu negara pertumbuhan ekonomi merupakan suatu indikasi penting dalam keberhasilan ataupun keterpurukan pembangunan ekonomi. Suatu negara akan mampu membangun atau dikatakan sebagai negara maju apabila memiliki wirausahawan minimal 2\% dari jumlah penduduknya (Alma, 2011:4). Menurut AIBI (Asosiasi Inkubator Bisnis Indonesia) menyatakan jumlah wirausahawan di negara Indonesia baru $0,18 \%$ atau sejumlah 400.000 jiwa dari jumlah penduduk 250 juta jiwa. Sebagai pembanding di AS 11,5\%, di China 10\%, di Singapura 7,2\% dan di Malaysia 4\%. (Rochmah, 2013).

Menurut Schumpeter (dalam Wibowo, 20011:20) peranan pengusaha dalam menciptakan pertumbuhan ekonomi dan para pengusaha merupakan golongan yang akan terus menerus membuat pembaharuan atau inovasi dalam ekonomi. Dalam menciptakan suatu kesempatan kerja dibutuhkan adanya sumber daya alam, sumber daya manusia dan modal oleh Basrowi (2011:10).

Perguruan tinggi sebagai institusi pendidikan ikut berpartisipasi aktif dan berperan serta dalam membangun ekonomi negara kita yang terpuruk. Banyak lulusan yang dihasilkan dari perguruan tinggi dengan Sumber Daya Manusia yang berkualitas ternyata masih belum mampu menghasilkan mahasiswa yang siap berwirausaha dengan mandiri. Usaha perguruan tinggi dengan memasukan mata kuliah kewirausahaan dalam semua prodi belum terlihat hasilnya.

Dari fenomena tersebut menarik untuk meneliti faktor-faktor yang menjadi alasan menjadi wirausaha pada mahasiswa. Mahasiswa yang akan menjadi subyek peniliti adalah mahasiswa Prodi Ekonomi, Prodi Matematika, Prodi PPKn STKIP PGRI Tulungagung yang telah memperoleh mata kuliah kewirausahaan dan telah menginjak semester akhir pada semua program studi di STKIP PGRI Tulungagung. Mahasiswa semester akhir dipilih menjadi responden karena mereka mendekati masa akhir studi dan segera memasuki angkatan kerja. Menjelang berakhirnya masa studi umumnya mereka mulai memikirkan pekerjaan yang akan ditekuni setelah lulus.

Menurut Basrowi (2011) diantara upaya penanggulan adalah meningkatkan sumber daya manusia, menciptakan lapangan kerja baru dan menumbuh kembangkan usaha wiraswasta. Menurut Ciputra (2008) menyatakan bahwa manusia menjadi sukses sebagai wirausaha tidak hanya mengandalkan bakat tapi juga ilmu Pengetahuan dan Pengalaman.

Menurut Slameto (2010) minat adalah rasa lebih suka dan rasa ketertarikan pada suatu hal atau aktivitas tanpa adanya yang menyuruh. Minat mahasiswa STKIP PGRI Tulungagung masih terlihat kurang dengan data jumlah mahasiswa yang mendaftar program PMW (Program Mahasiswa Wirausaha) sangat sedikit. Namun mahasiswa masih banyak belum tertarik untuk mencoba berwirausaha. Minat siswa dalam berwirausaha tidak timbul begitu saja tanpa adanya faktorfaktor yang mendukung. Menurut Iswandari (2013) ada tiga faktor intern yang mempengaruhi minat seseorang dalam berwirausaha yaitu motivasi, pengetahuan dan kepribadian dalam hal ini adalah keyakinan diri atau self eficacy.

Motivasi sebagai salah satu faktor penting yang mempengaruhi keyakinan dan keberanian seseorang untuk berwirausaha sangat perlu ditumbuhkan dalam diri mahasiswa. Motivasi dapat diberikan dalam bentuk latihan dengan adanya Program Mahasiswa Wirausaha (PMW). Untuk motivasi dari luar dapat timbul 
dari kampus maupun dari guru. Motivasi dapat diberikan dalam bentuk latihan dengan adanya Program Mahasiswa Wirausaha (PMW). Salah satu program yang ditujukan bagi mahasiswa untuk berwirausaha yang merupakan program dari Kopertis.

Menurut Bandura (1997) "keyakinan manusia mengenai efikasi diri mempengaruhi bentuk tindakan yang akan mereka pilih untuk dilakukan, sebanyak apa usaha yang akan mereka berikan ke dalam aktivitas ini, selama apa mereka akan bertahan menghadapi rintangan dan kegagalan, serta ketangguhan mereka mengikuti adanya kemunduran". Keyakinan dan kemampuan diri mahasiswa berkaitan dengan motivasinya. Manusia yang mempunyai efikasi diri tinggi yakin bahwa mereka dapat melakukan sesuatu yang mempunyai potensi untuk dapat mengubah kejadian di lingkunganya, akan lebih mungkin untuk bertindak mungkin menjadi daripada manusia mempunyai efikasi rendah. Sesuai dengan teori Luthans (2006) mendefinisikan keyakinan diri sebagai kepercayaan tentang kemampuanya untuk menggerakan motivasi, sumber daya kognitif, dan cara bertindak yang diperlukan untuk berhasil melaksanakan tugas konteks tertentu.

Penelitian ini berusaha menguji pengaruh faktor-faktor teridentifikasi dalam penelitian sebelumnya yaitu faktor-faktor yang mempengaruhi menjadi wirausaha yang meliputi efikasi diri, pengetahuan tentang kewirausahaan dan motivasi. Obyek peneliti ini adalah mahasiswa STKIP PGRI Tulungagung. Dipilihnya STKIP PGRI Tulungagung karena ini merupakan salah satu Perguruan Tinggi dikota Tulungagung yang telah banyak meluluskan sarjana-sarjana pendidikan Kabupaten Tulungagung banyak rnempunyai aset pariwisata, pertanian, perikanan juga ada pertambangan

Menurut Luthan (2006) efikasi diri (self efficacy) adalah kepercayaan seseorang bahwa ia memiliki kemampuan untuk mengerjakan dan menyelesaikan suatu pekerjaan pada suatu tingkat tertentu. Semakin tinggi rasa percaya diri seseorang dalam melaksanakan pekerjaannya maka aktivitas pribadi orang tersebut akan mendorong pencapaian tujuan atau keberhasilan pekerjaannya.

Menurut Bandura (1997) indikator efikasi diri terdiri dari: melihat orang lain, pengalaman, persuasi sosial dan faktor fisiologis yang selanjutnya akan diuraikan secara singkat. Melihat atau mengamati aktivitas seseorang secara berulang-ulang akan memudahkan kita untuk melakukan pekerjaan yang sama seperti yang pernah kita lihat dilakukannya (Modelling). Bandura (1997) proses demikian ini lebih efektif ketika seseorang melihat dirinya sama dengan model atau yang menjadi modelnya. Jika suatu model yang dirasa seperti dirinya memiliki kemampuan yang sama dan berhasil, hal ini akan meingkatkan efikasi diri si pemodel. Walaupun bukan sebagai hal yang berpengaruh seperti pengalaman masa lalu. Modelling adalah suatu pengaruh kuat ketika seseorang sama sekali tidak percaya atas kekuatan dirinya sendiri.Pengalamanmenurut Bandura (1997) pengalaman (experience) yaitu penguasaan suatu pekerjaan atau tugas karena sudah pernah melakukan pekerjaan tersebut sebelumnya. Pengalaman diri maupun pengalaman orang lain menyediakan informasi langsung mengenai kemampuan memprediksi dan mengatasi ancaman-ancaman untuk mengembangkan dan membuktikan efikasi diri yang kuat. Secara umum, keberhasilan akan meningkatkan efikasi diri, sedangkan kegagalan akan menurunkan efikasi diri. Persuasi Sosial (Social Persuasions) menurut Bandura 
(1997), persuasi sosial adalah meningkatnya rasa percaya diri dalam melakukan suatu kegiatan jika seseorang atau orang lain mengatakan bahwa kita mampu melakukannya. Perkataan orang lain secara signifikan berpengaruh terhadap kepercayaan diri seseorang. Perkataan positif akan menambah efikasi diri, sedang perkataan negatif akan menurunkan kepercayaan diri seseorang. Faktor Fisiologis (Phsyological Factors) menurut Luthans (2006) mengatakan bahwa orang sering mengandalkan perasaan mereka secara fisik dan emosi untuk menilai kapabilitas mereka. Seperti yang diungkap Bandura (1997) lebih dari sumber informasi lainnya, jika ada hal-hal negatif (misalnya orang sangat lelah dan atau tidak sehat secara fisik atau cemas/depresi, dan merasa tertekan), maka hal tersebut akan sangat mengurangi efikasi diri. Selanjutnya

Uraian di atas menunjukkan efikasi diri sangat menunjang kesuksesan seseorang yang dibentuk oleh 3 faktor yaitu: (1) melihat orang lain, (2) dukungan orang lain, (3) pengalaman. Dipilihnya indikator tersebut menurut peneliti telah disesuaikan dengan kapasitas dan kompetensi mahasiswa STKIP PGRI Tulungagung kurang dengan melihat lingkungan keluarga mereka kebanyakan bukan seorang wirausaha. Sehingga juga dapat mempengaruhi keyakinan mahasiswa.

Menurut (Iswandari, 2013) pengetahuan kewirausahaan adalah keseluruhan apa yang diketahui tentang segala bentuk informasi yang diolah dan berproses dalam ranah kognitif berupa ingatan dan pemahaman tentang cara berusaha sehingga menimbulkan keberanian mengambil resiko secara rasional dan logis dalam menangani suatu usaha. Saiman (2009) ada tiga faktor yang mempengaruhi seseorang tertarik dan menekuni dunia kewirausahaan (triggering event) yaitu faktor personal, faktor environment dan faktor sociological. Adanya sumber-sumber yang dapat dimanfaatkan, pelatihan, seminar bisnis dapat mendorong seseorang untuk berwirausaha (Alma, 2011). Pengetahuan kewirausahaan menurut Linan (2007) merupakan hasil dari proses belajar yang dialaminya. Salhi (2012) menyatakan ada 4 indikator yang mempengaruhi dari pengetahuan kewirausahaan yaitu: (1) pengetahuan dasar kewirausahaan, minat berusaha perlu diwujudkan oleh adanya informasi untuk menemukan atau menciptakan peluang bisnis sehingga membantu mewujudkan usaha mereka. (2) pengetahuan ide dan peluang usaha, pembentukan minat berusaha dalam menghasilkan suatu usaha memerlukan adanya pemikiran atau hal-hal baru yang terstruktur. (3) pengetahuan tentang aspek-aspek usaha, informasi yang ada akan menciptakan suatu proses melalui berbagai hambatan serta resiko yang akan dilalui untuk mewujudkan usaha mereka.

Armstrong (2008) mengatakan bahwa yang mendasari seseorang termotivasi untuk mengerjakan sesuatu secara individu adalah keinginan untuk memiliki sesuatu. Seorang pegawai yang memiliki motivasi untuk bekerja dengan menggunakan pengetahuan Indikator pada penelitan ini menggunakan Teori ERG dari Alderfer. Menurut Siagian (2013) mengatakan Alderfer dalam teori ini mengatakan satu set teori yang terdiri dari kebutuhan mengenai keberadaan, hubungan-hubungan, pertumbuhan. Alderfer menjelaskan dalam teorinya apabila usaha-usaha dalam memenuhi kebutuhan pada batas tertentu secara terus menerus tidak tercapai, maka pribadi itu mungkin akan mundur ke belakang ke perilaku untuk pemenuhan kebutuhan yang lebih actual. Ketiga kebutuhan ini merupakan focus alternatif teori kebutuhan dalam organisasasi. Pada dasarnya teori ini hanya 
penekanan kembali dari hirarki Maslow namun dalam menentukan prioritasnya lebih fleksibel seperti berikut : (a) kebutuhan existensi (keberadaan) mencakup kebutuhan faali dan keamanan yang ada pada Maslow, (b) kebutuhan relatedness (hubungan-hubungan) meliputi kebutuhan sosial dan penghargaan eksternal yang ada pada Maslow, (c) kebutuhan growth (pertumbuhan) meliputi faktor hormat internal pada kebutuhan penghargaan dan aktualisasi diri dari Maslow.

Minat menurut Shaleh (2004) adalah kecenderungan untuk memberikan perhatian dan bertindak perhatian dan bertindak terhadap orang, aktivitas atau situasi yang menjdi obyek dari minat tersebut dengan disertai perasaan senang. Menurut Aprilianty (2012) minat adalah sesuatu yang membangkitkan perhatian pada suatu hal. Menurut Yuliyaningsih (2013), minat berwirausaha merupakan keinginan, ketertarikan, serta kesediaan individu untuk bekerja keras dalam memenuhi kebutuhan hidupnya tanpa takut dengan resiko yang akan terjadi. Minat berwirausaha berasal dari dalam diri seseorang untuk menciptakan sebuah bidang usaha. Indikator minat berwirausaha (Super dan Crites dalam Iswandari, 2012) adalah: pengungkapan atau ucapan (expressed interest) dimana minat berwirausaha seseorang dapat diungkapkan dengan kata-kata tertentu Seseorang yang mempunyai minat berwirausaha akan diekspresikan (expressed interest) dengan ucapan atau pengungkapan. Misalnya: seseorang yang berminat wirausaha dalam bidang makanan kemudian dia mengatakan ingin membuka restoran. Tindakan atau perbuatan (manifest interest), seseorang jika ingin mengekspresikan minatnya dengan tindakan atau perbuatan yang sesuai dengan minat yang diinginkannya. Selain itu jika seseorang memiliki minat berwirausaha mereka pasti akan melakukan tindakan-tindakan yang mendukung usahanya tersebut.

Rumusan penelitian adalah :(1) apakah efikasi diri berpengaruh terhadap motivasi para mahasiswa STKIP PGRI Tulungagung; (2) apakah efikasi diri berpengaruh terhadap minat berwirausaha mahasiswa STKIP PGRI Tulungagung; (3) apakah pengetahuan kewirausahaan berpengaruh terhadap motivasi mahasiswa STKIP PGRI Tulungagung; (4) apakah pengetahuan kewirausahaan berpengaruh terhadap minat berwirausaha mahasiswa STKIP PGRI Tulungagung; (5) apakah motivasi berwirausaha berpengaruh terhadap minat berwirausaha STKIP PGRI Tulungagung; (6) apakah motivasi memediasi pengaruh efikasi diri, pengetahuan kewirausahaan terhadap minat berwirausaha mahasiswa STKIP PGRI Tulungagung.

\section{METODE PENELITIAN}

Pendekatan penelitian yang digunakan dalam penelitian ini adalah pendekatan kuantitatif. Jenis penelitian ini adalah penelitian eksplanatori (explanatory research). Variabel yang digunakan dalam penelitian ini adalah efikasi diri $\left(\mathrm{X}_{1}\right)$, pengetahuan kewirausahaan $\left(\mathrm{X}_{2}\right)$, motivasi $(\mathrm{Z})$, minat berwirausaha (Y). Populasi dalam penelitian ini adalah mahasiswa STKIP PGRI Tulungagung semeter akhir yang telah memperoleh mata kuliah kewirausahaan yang meliputi prodi Matematika, prodi PPKn, prodi Ekonomi sebanyak 619 mahasiswa. Jumlah sampel yang digunakan sebesar 243 mahasiswa. Pada penelitian ini menggunakan Structural Equation Modeling (SEM). Alasan mengunakan SEM adalah dikarenakan Augusty (2006) : Model dari penelitian ini 
agak kompleks (hubungan antar variabel), Sampel yang diambil adalah range (100-200), Indikator yang digunakan merupakan indikator reflektif (bukan formatif). Menurut Santoso (2011:2) pada prinsipnya di dalam SEM adalah ingin menganalisis hubungan kausal antar variabel eksogen dan endogen yang menunjukkan adanya perubahan nilai dari suatu variabel akan menghasilkan perubahan dari variabel lain, di samping itu juga dapat sekaligus untuk memeriksa validitas dan reliabilitas instrumen peneliti. SEM menganalisis struktur kovarian yang terdiri dari dua bagian yaitu model pengukuran dan model persamaan struktural.

Populasi dalam penelitian ini adalah mahasiswa STKIP PGRI Tulungagung prodi ekonomi, matematika dan PPKn semester akhir yang telah memperoleh mata kuliah kewirausahaan. Dengan sampel sebanyak 243 orang.

\section{HASIL PENELITIAN}

Tabel 1

Hasil Pengujian Hipotesis Model Persamaan Struktural

\begin{tabular}{|c|l|l|l|c|c|c|}
\hline Hip & \multicolumn{3}{|c|}{ Pengaruh } & Koefisien & C.R. & Keterangan \\
\hline $\mathrm{H}_{1}$ & Efikasi diri $\left(\mathrm{X}_{1}\right)$ & $\rightarrow$ & $\begin{array}{l}\text { Motivasi } \\
(\mathrm{Z})\end{array}$ & 0,110 & 1,492 & $\begin{array}{c}\text { Tidak } \\
\text { Signifikan }\end{array}$ \\
\hline $\mathrm{H}_{2}$ & Efikasi diri $\left(\mathrm{X}_{1}\right)$ & $\rightarrow$ & Minat $(\mathrm{Y})$ & 0,174 & 2,177 & Signifikan \\
\hline $\mathrm{H}_{3}$ & $\begin{array}{l}\text { Pengetahuan } \\
\text { wirausaha }\left(\mathrm{X}_{2}\right)\end{array}$ & $\rightarrow$ & $\begin{array}{l}\text { Motivasi } \\
(\mathrm{Z})\end{array}$ & 0,359 & 4,642 & Signifikan \\
\hline $\mathrm{H}_{4}$ & $\begin{array}{l}\text { Pengetahuan } \\
\text { wirausaha }\left(\mathrm{X}_{2}\right)\end{array}$ & $\rightarrow$ & Minat $(\mathrm{Y})$ & 0,034 & 0,414 & $\begin{array}{c}\text { Tidak } \\
\text { Signifikan }\end{array}$ \\
\hline $\mathrm{H}_{5}$ & Motivasi $(\mathrm{Z})$ & $\rightarrow$ & Minat $(\mathrm{Y})$ & 0,249 & 2,847 & Signifikan \\
\hline
\end{tabular}

Berdasarkan Tabel 1 dapat dibentuk persamaan struktural sebagai berikut : $\mathrm{Z}=0,110 \mathrm{X}_{1}+0,359 \mathrm{X}_{2}$

$\mathrm{Y}=0,174 \mathrm{X}_{1}+0,034 \mathrm{X}_{2}+0,249 \mathrm{Z}$

Berdasarkan tabel 2 dapat dijelaskan sebagai berikut :

1. Nilai koefisien jalur efikasi diri $\left(\mathrm{X}_{1}\right) \rightarrow$ motivasi $(\mathrm{Z})$ sebesar 0,110 , artinya jika efikasi diri naik maka motivasi akan naik sebesar 0,110. NilaiCritical Ratio sebesar $1,492<1,96$, maka dapat disimpulkan bahwa pengaruh efikasi diri terhadap motivasi tidak signifikan. Jadi hipotesis yang menyatakan efikasi diri berpengaruh signifikan terhadap motivasi ditolak.

2. Nilai koefisien jalur efikasi diri $\left(\mathrm{X}_{1}\right) \rightarrow$ minat $(\mathrm{Y})$ sebesar 0,174 , artinya jika efikasi diri naik maka minat akan naik sebesar 0,174. Nilai Critical Ratio sebesar 2,177> 1,96, maka dapat disimpulkan bahwa pengaruh efikasi diri terhadap minat signifikan. Jadi hipotesis yang menyatakan efikasi diri berpengaruh signifikan terhadap minat diterima.

3. Nilai koefisien jalur pengetahuan wirausaha $\left(X_{2}\right) \rightarrow$ motivasi $(Z)$ sebesar 0,359 , artinya jika pengetahuan wirausaha naik maka motivasi akan naik sebesar 0,359. Nilai Critical Ratio sebesar 4,642>1,96, maka dapat disimpulkan bahwa pengaruh pengetahuan wirausaha terhadap motivasi signifikan. Jadi hipotesis yang menyatakan pengetahuan wirausaha berpengaruh signifikan terhadap motivasi diterima. 
4. Nilai koefisien jalur pengetahuan wirausaha $\left(\mathrm{X}_{2}\right) \rightarrow$ minat $(\mathrm{Y})$ sebesar0,034, artinya jika pengetahuan wirausaha naik maka minat akan naik sebesar 0,414. Nilai Critical Ratio sebesar 0,414<1,96, maka dapat disimpulkan bahwa pengaruh pengetahuan wirausaha terhadap minat tidak signifikan. Jadi hipotesis yang menyatakan pengetahuan wirausaha berpengaruh signifikan terhadap minat ditolak.

5. Nilai koefisien jalur motivasi $(\mathrm{Z}) \rightarrow$ minat $(\mathrm{Y})$ sebesar 0,249 , artinya jika motivasi naik maka minat akan naik sebesar 0,249. Nilai Critical Ratio sebesar 2,847 > 1,96, maka dapat disimpulkan bahwa pengaruh motivasi terhadap minat signifikan. Jadi hipotesis yang menyatakan motivasi berpengaruh signifikan terhadap minat diterima.

\section{Pembahasan}

\section{Pengaruh Efikasi Diri terhadap Motivasi}

Berdasarkan hasil pengujian diperoleh hasil yang menunjukan bahwa efikasi diri tidak berpengaruh signifikan terhadap motivasi. Hasil tersebut dapat dilihat dari koefisien jalur efikasi diri $\left(\mathrm{X}_{1}\right)$ terhadap motivasi $(\mathrm{Z})$ sebesar 0,110 artinya jika efikasi diri naik maka motivasi naik sebesar 0,110 dan nilai critical ratio sebesar 1,492 < 1,96. Hal ini berarti bahwa efikasi diri mahasiswa STKIP PGRI Tulungagung tidak berpengaruh signifikan terhadap motivasi.

Berdasarkan hasil penelitian di atas penelitian ini tidak mendukung penelitian yang dilakukan oleh Armiati (2010) yang menyatakan efikasi diri berpengaruh positif dan signifikan terhadap motivasi berwirausaha mahasiswa. Namun penelitian ini mendukung penelitian yang dilakukan oleh Mei-hua Chen (2013) yang menyatakan efikasi diri tidak berpengaruh terhadap motivasi.

Berdasarkan hasil analisis menunjukkan bahwa pengaruh efikasi $\left(\mathrm{X}_{1}\right)$ diri terhadap motivasi $(\mathrm{Z})$ tidak signifikan. Temuan dalam penelitian ini pada variabel efikasi diri menunjukan bahwa mahasiswa STKIP PGRI Tulungagung kurang bisa mengevaluasi setiap pekerjaan, kurang bisa menjadikan pembelajaran dari setiap kegagalan dan kurang bisa mempertimbangkan resiko yang akan terjadi. Berdasarkan dari nilai ujian meskipun nilai ujian mereka bagus namun mereka belum mempunyai keyakianan diri untuk menjalankan teori yang telah dipelajari. Hal tersebut dikarenakan kurangnya jam praktek yang diberikan pada mahasiswa STKIP PGRI Tulungagung karena persentase untuk teori $80 \%$ sedang persentase untuk praktek hanya $20 \%$.

Pada variabel motivasi dapat ditemukam bahwa mahasiswa STKIP PGRI Tulungagung sudah bisa mempunyai gambaran dengan berwirausaha akan bebas menentukan dan mengatur sendiri pekerjaan dan waktunya, bisa menuangkan ideide kreatif yang dimiliki serta dengan berwirausaha tidak akan tertekan oleh kebijakan atasan, adanya semangat yang tinggi dari mahasiswa untuk bekerja lebih giat agar lebih maju dari teman-temnya. Selain itu mahasiswa STKIP PGRI Tulungagung juga telah mampu menjalin komunikasi dan menjalin jaringan dengan orang lain sehingga akan bisa menumbuhkan motivasi untuk berwirausaha.

Tidak berpengaruhnya efikasi diri terhadap motivasi dikarenakan oleh beberapa sebab. Seharusnya jika mahasiswa dapat menjadikan pengalaman sebagai pembelajaran maka efikasi dirinya tinggi sehingga akan mempengaruhi tingginya motivasinya dalam berwirausaha. Namun berbeda pada temuan ini, 
bahwa efikasi diri mahasiswa tidak berpengaruh terhadap motivasi. Ini dimungkinkan karena tingkat pengalaman mahasiswa yang kurang maka membuat mahasiswa kurang, hal tersebut dapat dilihat dari kurangnya kemampuan mahasiswa dalam menganalisa kegagalan dan kurangnya kemampuan mempertimbangkan segala resiko yang akan terjadi.

\section{Pengaruh Efikasi Diri terhadap Minat Berwirausaha}

Berdasarkan hasil pengujian diperoleh hasil yang menunjukan bahwa efikasi diri berpengaruh signifikan terhadap minat berwirausaha. Hasil tersebut dapat dilihat dari koefisien jalur efikasi diri $\left(\mathrm{X}_{1}\right)$ terhadap minat berwirausaha $(\mathrm{Y})$ sebesar 0,174 artinya jika efikasi diri naik maka minat berwirausaha naik sebesar 0,110 dan nilai critical ratio sebesar 2,177 > 1,96. Hal ini berarti bahwa efikasi diri mahasiswa STKIP PGRI Tulungagung mempengaruhi minat berwirausaha.

Dalam penelitian ini mendukung hasil penelitian terdahulu yang dilakukan oleh : Iswandari (2013), Armiati (2010), Indah (2013), Istibsyaroh (2013), Aprilianty (2013), Andrew (2012), Hasan (2012) yang menyatakan bahwa efikasi diri berpengaruh terhadap minat berwirausaha.

Dalam penelitian ini pada variabel efikasi diri menunjukan bahwa mahasiswa STKIP PGRI Tulungagung kurang bisa mengevaluasi setiap kegagalan, kurang bisa menjadikan pembelajaran dari setiap kegagalan dan tidak bisa mempertimbangkan resiko yang akan terjadi. Sehingga mahasiswa kurang memiliki efikasi diri. Namun dengan adanya dukungan orang lain terutama keluarga dan lingkungan sekitar juga dapat mendukung keyakinan diri mahasiswa STKIP PGRI Tulungagung. Dengan adanya dukungan tersebut berupa apresiasi positif serta kesamaan pendapat dari orang lain serta adanya ketertarikan mahasiswa saat melihat orang lain sukses serta keinginan untuk meniru kesuksesan tersebut akan sedikit menambah kayakinan mahasiswa.

\section{Pengaruh Pengetahuan Kewirausahaan terhadap Motivasi}

Berdasarkan hasil pengujian diperoleh hasil yang menunjukan bahwa pengetahuan kewirausaan berpengaruh signifikan terhadap motivasi berwirausaha. Hasil tersebut dapat dilihat dari koefisien jalur pengetahuan kewirausahaan $\left(\mathrm{X}_{2}\right)$ terhadap motivasi $(Z)$ sebesar 0,359 artinya jika pengetahuan kewirausahaan naik maka motivasi berwirausaha naik sebesar 0,359 dan nilai critical ratio sebesar $4,642>1,96$. Hal ini berarti bahwa pengetahuan kewirausahaan mahasiswa STKIP PGRI Tulungagung berpengaruh terhadap motivasi.

Hasil penelitian ini mendukung penelitian dari Istibasyaroh (2013), bahwa pengetahuan kewirausahaan dapat mempengaruhi motivasi berirausaha mahasiswa. Dipertegas dengan dukungan dari penelitian yang dilakukan oleh Kumara (2013) yang menyatakan pengetahuan kewirausahaan berpengaruh signifikan terhadap motivasi

Pengetahuan kewirausahaan berpengaruh signifikan terhadap motivasi mahasiswa STKIP PGRI Tulungagung didukung oleh temuan pada indikator pengetahuan tentang aspek-aspek usaha. Hal ini ditunjukan dalam temuan bahwa mahasiswa STKIP PGRI Tulungagung belum bisa menganalisa bagaimana lokasi usaha yang strategis, menganalisa bagaimanakah cara menjalankan modal yang dumilikinya serta bagaimana cara memberikan pelayanan yang baik pada 
konsumen. Hal tersebut dikarenakan masih kurangnya jam praktek langsung yang harus dilakukan mahasiswa.

Secara dapat dilihat dari nilai ujian tengah semester (UTS) maupun ujian akhir semester (UAS) cenderung bagus sehingga ini menggambarkan bahwa mahasiswa sudah memahami materi yang diajarkan. Namun ternyata setelah praktek dilakukan mahasiswa belum bisa mengaplikasikanya dengan baik sesuai teori yang didapat. Selain itu juga didukung oleh temuan dari variabel motivasi didominasi oleh indikator pertumbuhan. Hal ini dapat ditunjukan oleh temuan bahwa mahasiswa mempunyai keinginan untuk bekerja keras dan giat serta mau meningkatkan produktivitas agar lebih maju dari teman-teman yang lain sehingga hal ini dapat memotivasi mahasiswa untuk berwirausaha. Selain itu mahasiswa STKIP PGRI Tulungagung mampu menjalin komunikasi dengan sekitar dan terbuka pada setiap informasi yang ada sehingga banyak pengetahuan dari luar yang dapat menumbuhkan motivasi mahasiswa.

Hasil temuan tersebut menunjukan bahwa pengetahuan kewirausahaan memberikan sumbangan positif terhadap motivasi mahasiswa STKIP PGRI Tulungagung. Walaupun pengetahuan mahasiswa tentang penentuan lokasi usaha, pengelolaan modal dan bagaimana pelayanan yang baik mahasiswa STKIP PGRI Tulungagung masih sangat kurang namun mahsiswa STKIP PGRI Tulungagung masih bisa membaca peluang sekitar untuk menghasilkan sesuatu yang bernilai guna dan mampu berkomunikasi dan mampu menjalin hubungan dengan orang lain.

\section{Pengaruh Pengetahuan Kewirausahaan terhadap Minat Berwirausaha}

Berdasarkan hasil pengujian diperoleh hasil yang menunjukan bahwa pengetahuan kewirausahaan tidak berpengaruh signifikan terhadap minat berwirausaha. Hasil tersebut dapat dilihat dari koefisien jalur pengetahuan kewirausahan $\left(\mathrm{X}_{2}\right)$ terhadap minat berwirausaha $(\mathrm{Y})$ sebesar 0,034 artinya jika pengetahuan kewirausahaan naik maka minat berwirausaha naik sebesar 0,034 dan nilai critical ratio sebesar $0,414<1,96$. Hal ini berarti bahwa pengetahuan kewirausahaan mahasiswa STKIP PGRI Tulungagung tidak berpengaruh terhadap minat berwirausaha.

Hasil penelitan ini tidak mendukung hasil penelitan yang dilakukan oleh Eka Aprilianty (2012) yang menyatakan pengetahuan berpengaruh signifikan dan positif terhadap minat berwirausaha. Hal ini sesuai seperti yang dikatakan oleh Iswandari (2013) pengetahuan kewirausahaan adalah keseluruhan apa yang diketahui tentang segala bentuk informasi yang diolah dan berproses dalam ranah kognitif berupa ingatan dan pemahaman tentang cara berusaha sehingga menimbulkan keberanian mengambil resiko secara rasional dan logis dalam menangani suatu usaha.

Pengetahuan kewirausahan tidak berpengaruh terhadap minat berwirausaha. Temuan dalam penelitian ini pengetahuan tentang kewirausahaan sudah diperoleh mahasiswa melalui teori yang diberikan. Dalam temuan ini menunjukan bahwa mahasiswa STKIP PGRI Tulungagung kurang memiliki gambaran tentang aspekaspek usaha yang meliputi lokasi yang akan digunakan untuk membuka usaha, bagaimana lingkungan konsumen sekitar usaha, bagaimanakah modal yang akan dialokasikan dalam usaha serta pelayanan terhadap konsumen. Kurangnya jam 
praktek yang diberikan pada mahasiswa sehingga menyebabkan mahasiswa kurang mengenal dan menganalisa langsung aspek-aspek tersebut.

Selain itu juga didukung oleh temuan pada variabel minat berwirausaha. Hasil temuan ini ditunjukan bahwa mahasiswa STKIP PGRI Tulungagung memiliki perasaan senang melakukan kegiatan usaha serta senang melihat pameran-pameran kewirausahaan. Hal ini dimungkinkan karena kegiatan-kegiatan tersebut lebih dapat dilihat secara langsung manfaat yang dihasilkan. Selain itu temuan lain bahwa mahasiswa STKIP PGRI Tulungagung juga senang membaca buku-buku tentang keirausahaan atau buku motivasi-motivasi dari orang lain yang sukses dalam dunia usaha

Sehingga tidak berpengaruhnya pengetahuan kewirausahaan terhadap minat dikarenakan oleh beberapa sebab rendahnya pengetahuan mahasiswa yang meliputi bagaimanakah lokasi yang strategis untuk membuka usaha, bagaimanakah cara mengalokasikan modal yang ada serta bagaimana cara memberikan pelayanan yang baik pada konsumen. Seharusnya dengan pengetahuan rendah maka minat mahasiswa juga rendah. Namun berbeda dengan temuan pada penelitian ini bahwa dengan kurangnya pengetahuan tentang aspekaspek usaha tersebut di atas namun tetap membuat mahasiswa tertarik untuk membuka usaha. Hal tersebut dikarenakan mahasiswa masih memiliki kemampuan menghasilkan ide-ide baru untuk memanfaatkan sesuatu sekitar sehingga menghasilkan nilai lebih serta kemampuan membaca peluang usaha yang ada di sekitar.

\section{Pengaruh Motivasi terhadap Minat Berwirausaha}

Berdasarkan hasil pengujian diperoleh hasil yang menunjukan bahwa motivasi berpengaruh signifikan terhadap minat berwirausaha. Hasil tersebut dapat dilihat dari koeisien jalur motivasi (Z) terhadap minat berwirausaha (Y) sebesar 0,034 artinya jika pengetahuan kewirausahaan naik maka minat berwirausaha naik sebesar 0,249 dan nilai critical ratio sebesar 0,2,847 > 1,96. Hal ini berarti bahwa motivasi mahasiswa STKIP PGRI Tulungagung berpengaruh terhadap minat berwirausaha.

Dalam penelitian ini mendukung penelitian terdahulu yang dilakukan oleh Armiati (2010), Iswandari (2013) bahwa motivasi mempengaruhi minat berwirausaha mahasiswa. Namun penelitian ini tidak mendukung penelitian yang dilakukan oleh Renko (2011) yang menyatakan motivasi tidak dapat membentuk minat berwirausaha

Berdasarkan temuan bahwa mahasiswa STKIP PGRI Tulungagung mempunyai tingkat bekerja keras, giat berusaha tinggi keinginan untuk meningkatkan produktivitasnya juga tinggi serta keinginan lebih maju dari temanteman yang lainya dapat menumbuhkan motivasi dalam diri mahasiswa Selain itu kemampuan mahasiswa dalam berkomunikasi dengan lingkungan sekitar, kemampuan menjalin jaringan serta terbuka dengan info dari luar sehingga akan mempengaruhi mahasiswa STKIP PGRI Tulungagung untuk mempunyai keinginan atau ketertarikan untuk membuka wirausaha.

Selain itu didukung temuan pada indikator variabel minat berwirausaha menunjukan bahwa mahasiswa STKIP PGRI Tulungagung senang menghadiri kegiatan-kegiatan pelatihan yang bertema kewirausahaan serta mahasiswa juga memiliki kesenangan membaca buku-buku motivasi tentang kewirausahaan. Hasil 
temuan tersebut menunjukan bahwa motivasi memberikan sumbangan positif terhadap minat berwirausaha mahasiswa STKIP PGRI Tulungagung. Dengan semangat bekerja keras dan kemampuan meningkatkan produktivitasnya akan dapat mempengaruhi mahasiswa untuk yakin dalam berwirausaha serta menjalin komunikasi dengan sekitarnya sehingga akan membangun pemikiran positif dalam dunia usaha sehingga mendorong keinginan dan ketertarikan mahasiswa untuk berwirausaha. Dengan komunikasi dengan dunia luar maka akan menambah wawasan mahasiswa untuk mempersiapkan diri terjun ke dunia usaha. Denagn sedikitnya minat terhadap PMW itu menunjukan mahasiswa ingin berwirausaha mahasiswa cenderung ingin berwirausaha mandiri sendiri tanpa mengikuti program-progarm dari institusi.

\section{Motivasi dapat Memediasi Efikasi Diri terhadap Minat Berwirausaha.}

Berdasarkan pengujian dengan uji Sobel diperoleh hasil yang menunjukan bahwa motivasi tidak terbukti memediasi efikasi diri terhadap minat berwirausaha. Hasil tersebut dapat dilihat dari t hitung koefisien tidak langsung sebesar sebesar $1,351<$ nilai $\mathrm{Z}$ test $(1,96)$, menunjukkan bahwa keofisien tidak langsung jalur Efikasi diri $\left(\mathrm{X}_{1}\right) \rightarrow$ motivasi $(\mathrm{Z}) \rightarrow$ minat $(\mathrm{Y})$ sebesar 0,027 tidak signifikan.

Hasil penelitian ini tidak sesuai dengan penelitian terdahulu yang dilakukan oleh Armiati (2010) yang menyatakan motivasi dapat memediasi antar efikasi diri mahasiswa terhadap minat berwirausaha. Motivasi sebagai variabel perantara dapat memperbesar pengaruhnya terhadap minat berwirausaha mahasiswa.

Motivasi tidak terbukti memediasi efikasi diri terhadap minat berwirausaha. Temuan dalam penelitian ini minat berwirausaha mahasiswa tidak perlu dimediasi motivasi. Dengan pengaruh efikasi diri secara langsung sudah dapat mempengaruhi minat berwirausaha mahasiswa. Temuan ini didukung oleh indikator pada variabel motivasi yang menunjukan bahwa mahasiswa STKIP PGRI Tulungagung mempunyai kesadaran bahwa dengan berwirausaha akan bebas menentukan waktu, ide sendiri serta tanpa adanya tekanan dari atasan.

Temuan pada variabel efikasi yaitu mahasiswa STKIP PGRI Tulungagung kurang bisa mengevaluasi pekerjaan, kurang bisa mempertimbangkan segala resiko serta kurang menjadikan kegagalan sebagai pembelajaran. Meskipun mahasiswa kurang mampu dalam hal tersebut dengan tambahan dukungan dari orang tua dan lingkungan sekitar, dengan kesenangan melihat dan meniru kesuksesan orang lain sudah dapat mempengaruhi minat berwirausaha mahasiswa. Sehingga motivasi yang tinggi tidak akan berpengaruh karena meskipun efikasi diri dapat berpengaruh terhadadp minat pengaruhnya sangat kecil.

Selain itu temuan pada variabel minat berwirausaha pada indikator tindakan. Hal ini ditunjukan mahasiswa STKIP PGRI Tulungagung mempunyai rasa tertarik melihat kegiatan-kegiatan yang berhubungan dengan bisnis, senang membaca buku-buku tentang kiat-kiat orang sukses itu sudah dapat menumbuhkan minat berwirausaha mahasiswa. Meskipun data dari minat pendaftar PMW (program mahasiswa wirausaha) sedikit namun itu sudah membuktikan pengaruh efikasi diri terhadap minat berwirausaha meski pengaruhnya rendah. Sehingga motivasi yang tinggi tidak akan berpengaruh karena meskipun efikasi diri dapat berpengaruh terhadap minat pengaruhnya sangat kecil. 
Berdasar pembahasan tersebut untuk mencapai minat berwirausaha yang tinggi tidak pelu mediasi motivasi. Oleh karena itu lebih baik langsung dari efikasi diri terhadap peningkatan minat berwirausaha. Dengan kemampuan mahasiswa untuk mengevaluasi pekerjaan ataupun mengetahuai tingkat resiko, melihat kesuksesan orang lain akan dapat menumbuhkan minat secara langsung tanpa adanya motivasi.

\section{Motivasi dapat Memediasi Pengetahuan Kewirausahaan terhadap Minat \\ Berwirausaha.}

Berdasarkan pengujian dengan uji Sobel diperoleh hasil yang menunjukan bahwa motivasi terbukti memediasi pengetahuan kewirausahaan terhadap minat berwirausaha. Hasil t hitung koefisien tidak langsung sebesar 2,81> nilai $\mathrm{Z}$ test $(1,96)$, menunjukkan bahwa koefisien tidak langsung jalur pengetahuan $\rightarrow$ motivasi $(\mathrm{Z}) \rightarrow$ minat $(\mathrm{Y})$ sebesar 0,089 signifikan. Motivasi terbukti dapat memediasi efikasi diri terhadap minat berwirausaha. Temuan dalam penelitian ini dapat didukung oleh indikator bahwa keinginan yang kuat dari mahasiswa untuk bekerja keras dan giat berusaha serta keinginan untuk lebih maju dari temanteman yang lain itu Hal itu menunjukan bahwa mahasiswa sudah memiliki dasar untuk tertarik terhadap minat berwirausaha. Dengan didukung oleh kemampuan mahasiswa untuk berkomunikasi dengan lingkungan sekitar dan kemampuan menjalin hubungan dengan rekan kerja akan lebih mendominasi minat berwirausaha.

Temuan dalam variabel pengetahuan kewirausahaan pada variabel ini menunjukan bahwa mahasiswa STKIP PGRI Tulungagung kurang memiliki gambaran tentang aspek-aspek usaha yang meliputi lokasi mendirikan usaha, bagaimana modal usaha yang serta pelayanan terhadap konsumen. Minimnya jam praktek dikarenakan masih barunya mata kuliah kewirausahaan masuk dalam semua mata kuliah sehingga penerapannya masih melaui pengenalan dengan memperbanyak teori. Temuan lain bahwa mahasiswa STKIP PGRI Tulungagung mampu mencetuskan ide-ide baru serta mampu menangkap peluang usaha apa yang ada di sekitar untuk dimanfaatkan sehingga menghasilkan nilai lebih. Hal tersebut dapat dilihat saat ada tugas mata kuliah kewirausahaan praktek kelompok maupun individu untuk menghasilkan suatu produk tertentu, mahasiswa banyak yang menyuguhkan produk-produk baru yang inovatif.

Berdasarkan hasil penelitian didapat temuan ini bahwa untuk mencapai tingkat minat berwirausaha yang tinggi perlu melalui mediator motivasi. Dengan adanya semangat yang giat bekerja, kemampuan berkomunikasi dari mahasiswa STKIP PGRI Tulungagung akan menambah pengetahuan mahasiswa tentang wirausaha sehingga akan memotivasi mahasiswa untuk tertarik dan berkeinginan berwirausaha.

\section{KESIMPULAN}

Berdasarkan hasil penelitian yang telah diuraikan, maka dapat disimpulkan bahwa: Efikasi diri tidak berpengaruh terhadap motivasi. Efikasi diri berpengaruh terhadap minat berwirausaha. Pengetahuan kewirausahan berpengaruh terhadap motivasi. Pengetahuan kewirausahaan tidak berpengaruh terhadap minat berwirausaha. Motivasi berpengaruh terhadap minat berwirausaha. Motivasi tidak 
dapat memediasi efikasi diri terhadap minat berwirausaha. Motivasi memediasi pengetahuan kewirausahaan terhadap minat berwirausaha.

\section{DAFTAR RUJUKAN}

Alma, Buchari. (2011). Kewirausahaan. Edisi I. Cetakan delapanbelas. Bandung: Alfabeta

Aprilianty, Eka. (2012). Pengaruh Kepribadian Wirausaha, Pengetahuan Kewirausahaan Dan Lingkungan Terhadap Minat Berwirausaha Siswa SMK.Jurnal Pendidikan Vokasi, Vol 2,Nomor 3, Tahun 2012. Pp 311-324

Armstrong Michael.(2008).A Hand Book Personnel Management Practice. Fourth Edition. Kogan Page Limited, London.

Bandura, A. (1997).Self Efficacy The Exercise of Control, First Edition. Freeman: New York

Basrowi, (2011).Kewirausahaan,Edisi pertama. Bogor: Ghalia Indonesia.

Ciputra. (2008). The Ciputra Way. Edisi pertama. Jakarta: Gramedia

Hamzah, B. Uno. (2008). Teori Motivasi dan Pengukuranya. Edisi Pertama. Cetakan Ketiga. Jakarta: Bumi Akasara.

Iswandari, Asti. 2013. Pengaruh Motivasi Intrinsik, Pengetahuan Kewirausahaan dan Kepribadian terhadap Minat Berwirausaha Pada Siswa SMKN 12 Surabaya. Tesis Magister Pendidikan, Universitas Negeri Surabaya.

Luthans, (2006), Organizatioal Behavior, Ten Edition, McGraw-Hill International Edition Printed in Singapore.

Saiman, Leonardus. (2009). Kewirausahaan Teori Praktik Dan Kasus-Kasus. Edisi Pertama. Jakarta: Salemba Empat.

Salhi, Bassem. (2012). Student And Entreprenuership: Effect of The Training.

Journal of Research in Educational Sciences. Volume 3 Issue 5. Pp 19-34.

Schunk and Pitrick. (2012). Motivasi Pendidikan. Edisi kelima. Jakarta: Erlangga.

Shaleh dan Muhbib Abdul. (2005). Psikologi Suatu Pengantar Dalam Perspektif Islam. Edisi Pertama. Jakarta: Kencana.

Siagian, P Sondang. (2013). Teori Motivasi dan Aplikasinya. Edisi Pertama. Jakarta: Rineka Cipta.

Slameto. (2010). Belajar dan Faktor-Faktor Yang Mempengaruhinya. Edisi Revisi. Jakarta: Rineka Cipta.

Suryana. (2013). Kewirausahaan, pedoman Praktis:Kiat dan Proses Menuju Sukses.Edisi Empat.Jakarta:Salemba Empat. 